Article

\title{
Hepatoprotective Effects of Pleurotus ostreatus Protein Hydrolysates Yielded by Pepsin Hydrolysis
}

\author{
Liwei Zhang ${ }^{1}$, , Yuxiao Lu ${ }^{2}$, Xiaobin Feng ${ }^{3}$, Qinghong Liu ${ }^{3, *}$, Yuanhui Li ${ }^{3}$, Jiamin $\mathrm{Hao}^{3}$, \\ Yanqiong Wang ${ }^{3}$, Yongqiang Dong ${ }^{3}$ and Huimin David Wang $4,5,6,7, *$ (D) \\ 1 Department of Microbiology and Immunology, China Agricultural University, Beijing 100193, China; \\ Biozhangliwei@163.com \\ 2 Department of Environment and Chemical Engineering, Tangshan College, Tangshan 063000, China; \\ luyuxiao2006@126.com \\ 3 Department of Vegetables, College of Horticulture, China Agriculture University, Beijing 100193, China; \\ fengxiaobin@126.com (X.F.); lyh188116@163.com (Y.L.); hjm20010221@163.com (J.H.); \\ wyq116113@163.com (Y.W.); yqdong96@163.com (Y.D.) \\ 4 Graduate Institute of Biomedical Engineering, National Chung Hsing University, Taichung 402, Taiwan \\ 5 Graduate Institute of Medicine, College of Medicine, Kaohsiung Medical University, Kaohsiung 807, Taiwan \\ 6 Department of Medical Laboratory Science and Biotechnology, China Medical University, \\ Taichung City 404, Taiwan \\ 7 College of Food and Biological Engineering, Jimei University, Xiamen 361021, China \\ * Correspondence: qhliu@cau.edu.cn (Q.L.); davidw@dragon.nchu.edu.tw (H.D.W.); \\ Tel.: +86-10-6273-2578 (Q.L.); +886-4-22840733 (ext. 651) (H.D.W.); Fax: +886-4-22852242 (H.D.W.)
}

Received: 23 April 2020; Accepted: 9 May 2020; Published: 26 May 2020

\begin{abstract}
Pleurotus ostreatus protein extract (POPE) was prepared by the alkali precipitation method with $0.3 \%(w / v)$ NaOH. POPEP-III with a MW of 3000-5000 Da was acquired by pepsin enenzymatic hydrolysis. POPEP-III displayed noteworthy effects of 1,1-diphenyl-2-picrylhydrazyl DPPH and $\mathrm{H}_{2} \mathrm{O}_{2}$ scavenging activities, $\mathrm{Fe}^{2+}$ chelating ability, lipid peroxidation inhibition capacity, and metal reducing power. The administration of POPEP-III in mice significantly prevented prior $\mathrm{CCl}_{4}$-induced strengthen serum ALT and AST activities, changing from 365.44 $\pm 36.87 \mathrm{IU} / \mathrm{L}$ to $220.23 \pm 22.27 \mathrm{IU} / \mathrm{L}$ and $352.52 \mathrm{IU} / \mathrm{L}$ to $206.75 \pm 17.26 \mathrm{IU} / \mathrm{L}$, respectively $(p<0.001)$, and suppressed hepatic malondialdehyde (MDA) formation from $15.28 \pm 3.47 \mathrm{nmol} / \mathrm{mg}$ prot to $10.04 \pm 2.06 \mathrm{nmol} / \mathrm{mg}$ prot $(p<0.001)$. Mice treated with POPEP-III demonstrated augmented activities of superoxide dismutase (SOD) in the liver, from $187.49 \pm 19.81 \mathrm{U} / \mathrm{mg}$ prot to $233.35 \pm 34.23 \mathrm{U} / \mathrm{mg}$ prot, and of glutathione peroxidase (GSH-Px), from $84.01 \pm 14.54 \mathrm{U} / \mathrm{mg}$ prot to $115.9 \pm 16.57 \mathrm{U} / \mathrm{mg}$ prot $(p<0.05)$. POPEP-III also prevented $\mathrm{CCl}_{4}$-induced oxidative liver histological alteration. The results suggest that POPEP-III can protect the liver from $\mathrm{CCl}_{4}$-induced oxidative damage.
\end{abstract}

Keywords: Pleurotus ostreatus; enenzymatic hydrolysis; peptide; antioxidant; hepatoprotective activity

\section{Introduction}

As one of the most important organs, the liver plays crucial roles in protein, lipid, saccharide, and drug metabolism in the human body [1,2]. When the liver is exposed to excessive dietary fats, sugars and proteins, alcohols, or drugs, the heavy burden applied on the liver creates difficulty and might lead to liver diseases. In liver metabolism, some of these substances are transformed into free radical-mediated ROS by cytochrome P450 [3]. Liver diseases are common, inducing death at a high ratio of approximately $2 \%$ of all death [4]. Liver diseases, such as subclinical icteric hepatitis, hepatic fibrosis, cirrhosis and hepatocellular carcinoma, are related to free radical-mediated ROS. ROS can be 
generated in the liver mitochondria [5] and participate in the process of liver disease induction and development [6-8].

Free radical-mediated reactive oxygen species (ROS) have attracted appreciable attention based on their role in liver diseases and current methods for scavenging of $\mathrm{ROS}$. $\mathrm{CCl}_{4}$, a classical hepatotoxin, is reductively de-halogenated by cytochrome $\mathrm{P} 450$ to trichloromethyl free radicals $\left(\mathrm{CCl}_{3} \mathrm{OO} \cdot\right.$ or $\left.\cdot \mathrm{CCl}_{3}\right)$ and depletion of antioxidant enzymes in hepatic parenchyma cells and initiates the process of lipid peroxidation [8]. To protect the liver from damaging oxidation, numerous antioxidants have been explored. Aqueous, alcoholic, or supercritical $\mathrm{CO}_{2}$ extracts with antioxidant activity from selected medicinal herbs demonstrated hepatoprotective effects, although the substances in these extracted mixtures are structurally unclear [9-12]. One antioxidant chemical, silymarin from the Silybum marianum seeds, is commonly applied for hepatoprotection [13] and has side effects that include gastrointestinal complaints. Currently, mushrooms are increasingly under examination for their hepatoprotective values. Among the mushrooms explored for hepatoprotective substances, polysaccharides were ranked as the predominant component, and certain mixtures extracted from mushrooms by alcohol, water or other solvents have become topics of research [14-16]. Notably little research has focused on the hepatoprotective peptides from mushrooms [17], especially the hydrolysates from mushroom proteins.

Pleurotus ostreatus is widely cultivated around the world and is reported to contain bioactive compounds that can protect health due to their antioxidant properties. Among these compounds, $P$. ostreatus polysaccharides have attracted increasing attention $[18,19]$. Selected compounds extracted by ethanol from $P$. ostreatus showed high antioxidant activities, but the constituent was unclear $[20,21]$. An extraction with water from P. ostreatus solid culture presented immune-nutritional recovery [22]. Polysaccharides from P. ostreatus are of interest due to their multiple bioactivities, including antitumor, anti-inflammatory and cytotoxic effects [23]. Proteins in P. ostreatus have many bioactivities, including anti-tumor effects and use as an adjuvant for HBV DNA vaccine $[24,25]$. However, most of the previous works were relative to the nutritional evaluation for mushroom proteins, and few current studies focus on the bioactive natural component of low molecular weight peptides with multi-action bioactivity hydrolyzed by enzymes from the P. ostreatus proteins or other edible mushrooms. As the output of P. ostreatus is tremendous, it is very important to develop the procedure of health-keeping to extend the industry chain, and improve people's health with the natural products respectively. In our study, the antioxidant activity of $P$. ostreatus protein hydrolysates obtained with five proteases was investigated in vitro using biochemical assays. The highest antioxidant activity fractionated hydrolysates were refined through ultrafiltration. Moreover, the fraction with the highest antioxidant activity was investigated via an in vivo model of $\mathrm{CCl}_{4}$ intoxication. Physical characteristics, such as the degree of hydrolysis and amino acid composition of the hydrolysates fractions, were explored.

\section{Results}

\subsection{Degree of Hydrolysis}

Different efficiency was acquired in hydrolyzing POPE for the peptide bonds, as the five enzymes recognize different bonds and function differently. Among pepsin, trypsin, dispase, papain, and bromelin, pepsin had the highest efficiency in POPE hydrolysis (Table 1). The statistics indicated a mild DH of $16.01 \pm 0.12 \%$ after POPE incubation with pepsin. Hydrolysis proceeded for $1 \mathrm{~h}$ at $37^{\circ} \mathrm{C}$ and with $\mathrm{pH}$ 2.0. DH is defined as the percentage of peptide bonds cleaved. It was well established that $\mathrm{DH}$ can affect the functionality of hydrolysates, including antioxidant activity or reducing power. Generally, these effects become more evident when DH is modified more extensively. 
Table 1. Degree of Hydrolysis for POPE hydrolyzed by Pep, Pepsin-treated; Try, trypsin-treated; Dis, dispase-treated; Pap, papain-treated and Bro, bromelin-treated. The fractions ( $\mathrm{mw}<10 \mathrm{kDa}$ ) were designed as peptide, and the $\mathrm{DH}$ was calculated as $\mathrm{DH}=$ (weight of fraction (5-10 kDa) + weight of fraction $(3-5 \mathrm{kDa})+$ weight of fraction $(<3 \mathrm{kDa})) /$ weight of POPE. The values are presented as the mean \pm SD.

\begin{tabular}{lcccccc}
\hline & $\begin{array}{c}\text { POPE } \\
(\mathbf{m g})\end{array}$ & $\begin{array}{c}>\mathbf{1 0} \mathbf{~ k D a} \\
\mathbf{( m g})\end{array}$ & $\begin{array}{c}\mathbf{5 - 1 0} \mathbf{~ k D a} \\
\mathbf{( m g})\end{array}$ & $\begin{array}{c}\mathbf{3}-\mathbf{5} \mathbf{~ k D a} \\
\mathbf{( m g})\end{array}$ & $\begin{array}{c}<3 \mathbf{~ k D a} \\
\mathbf{( m g})\end{array}$ & DH (\%) \\
\hline Pep & 500 & $319.96 \pm 3.15$ & $45.76 \pm 1.15$ & $23.15 \pm 0.86$ & $11.14 \pm 0.19$ & $16.01 \pm 0.12$ \\
Try & 500 & $431.77 \pm 5.31$ & $34.79 \pm 2.19$ & $19.68 \pm 1.17$ & $10.32 \pm 1.39$ & $12.96 \pm 0.33$ \\
Dis & 500 & $429.63 \pm 7.31$ & $44.39 \pm 0.98$ & $17.93 \pm 2.87$ & $9.68 \pm 2.63$ & $14.40 \pm 0.19$ \\
Pap & 500 & $434.75 \pm 4.39$ & $39.37 \pm 2.33$ & $20.19 \pm 1.75$ & $10.17 \pm 3.18$ & $13.95 \pm 0.22$ \\
Bro & 500 & $430.07 \pm 8.63$ & $40.33 \pm 1.77$ & $19.47 \pm 0.96$ & $8.65 \pm 1.19$ & $13.67 \pm 0.96$ \\
\hline
\end{tabular}

\subsection{Amino Acid Composition}

The amino acid compositions of the hydrolysates suggested that they are rich in Leu, Phe, Glu, Met, Ala, Val, and Asp (Table 2). In addition, the THAA content in POPEP-III was higher than the other three fractions. For protein hydrolysate and peptides, the higher content in hydrophobicity the higher solubility in lipid they have. Moreover, high solubility enhances their antioxidant activity [26]. These highest antioxidant activities were presumably because of the highest content of THAA.

Table 2. Amino acid compositions of POPE and ultrafiltrated POPEP fractions.

\begin{tabular}{|c|c|c|c|c|c|c|}
\hline \multicolumn{2}{|c|}{ Amino Acid (g/100 g) } & \multirow{2}{*}{$\begin{array}{c}\text { POPE } \\
8.02\end{array}$} & \multirow{2}{*}{$\begin{array}{c}\begin{array}{c}\text { POPEP-I } \\
\text { (>10 kDa) }\end{array} \\
7.89\end{array}$} & \multirow{2}{*}{$\begin{array}{c}\begin{array}{c}\text { POPEP-II } \\
\text { (5-10 kDa) }\end{array} \\
5.39\end{array}$} & \multirow{2}{*}{$\begin{array}{c}\text { POPEP-III } \\
\text { (3-5 kDa) }\end{array}$} & \multirow{2}{*}{$\begin{array}{c}\begin{array}{c}\text { POPEP-IV } \\
\text { (<3 kDa) }\end{array} \\
7.78\end{array}$} \\
\hline \multirow{8}{*}{ Hydrophobic } & Phe & & & & & \\
\hline & Leu & 8.56 & 8.82 & 5.84 & 7.11 & 11.6 \\
\hline & Ala & 5.67 & 5.83 & 4.39 & 5.13 & 6.13 \\
\hline & Met & 13.8 & 11.04 & 11.95 & 11.52 & 13.02 \\
\hline & Val & 6.52 & 5.57 & 5.08 & 6.05 & 5.99 \\
\hline & Ile & 5.45 & 4.84 & 4.17 & 4.94 & 4.84 \\
\hline & Gly & 3.96 & 3.62 & 4.75 & 4.48 & 3.08 \\
\hline & Pro & 3.53 & 2.57 & 3.51 & 4.02 & 3.19 \\
\hline \multirow{9}{*}{ Hydrophilic } & Thr & 3.09 & 4.40 & 2.89 & 3.53 & 3.48 \\
\hline & Ser & 3.64 & 3.84 & 3.94 & 3.23 & 4.27 \\
\hline & Cys & 2.35 & 2.20 & 4.35 & 1.88 & 1.21 \\
\hline & Tyr & 6.74 & 8.20 & 4.91 & 4.66 & 4.6 \\
\hline & Lys & 3.1 & 2.75 & 3.19 & 2.27 & 1.94 \\
\hline & Arg & 4.28 & 4.28 & 3.81 & 3.35 & 4.6 \\
\hline & His & 1.39 & 1.45 & 1.39 & 1.09 & 1 \\
\hline & Asp & 6.74 & 7.22 & 6.71 & 7.21 & 6.18 \\
\hline & Glu & 9.2 & 8.91 & 13.37 & 11.32 & 8.31 \\
\hline
\end{tabular}

\subsection{Preparation of Protein Hydrolysatess and Antioxidant Activity}

Five different proteases, i.e., pepsin, trypsin, dispase, papain and bromelin, originating from different sources were used in the enzymatic hydrolysis of POPE. The antioxidant activities of the hydrolysate hydrolyzed by each protease are shown in Figure 1 and Table 3. Among the hydrolysates, POPEP derived from POPE hydrolyzed by pepsin showed the strongest antioxidant activity. This suggested that when disrupted by proteases, the active amino acids of protein might be exposed, and the antioxidant activity increases [27]. 

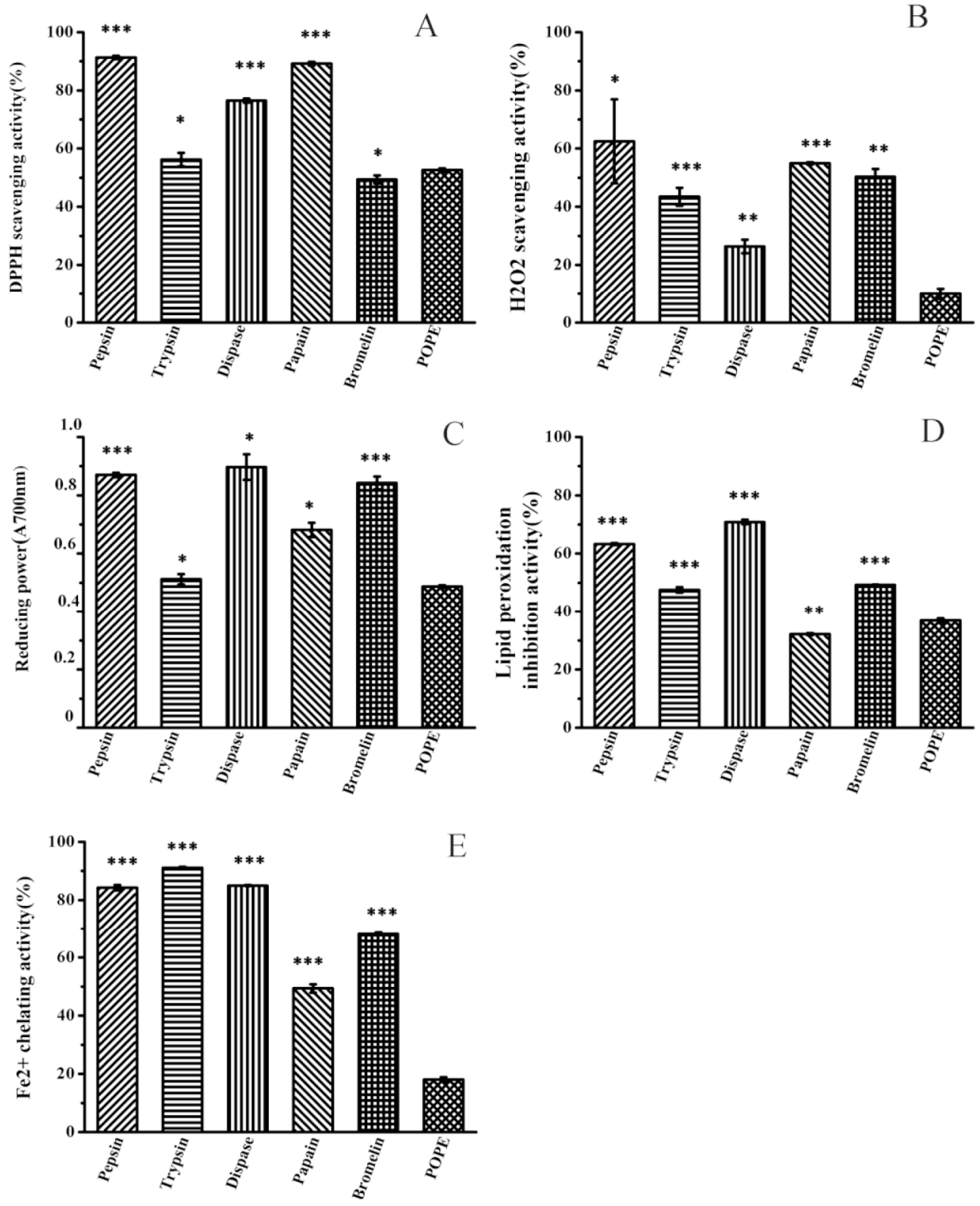

Figure 1. Comparison of in vitro antioxidant effects of P. ostreatus protein hydrolysate: Pep, Pepsin-treated; Try, trypsin-treated; Dis, dispase-treated; Pap, papain-treated and Bro, bromelin-treated. (A) DPPH scavenging activity. (B) Hydrogen peroxide scavenging activity. (C) Reducing power. (D) Inhibitory effect on lipid peroxidation. (E) $\mathrm{Fe}^{2+}$ ion chelating activity. The values are presented as the mean values $\pm \mathrm{SD}(\mathrm{n}=3) .\left({ }^{* * *}\right) p<0.001,\left({ }^{* *}\right) p<0.01$, and $\left({ }^{*}\right) p<0.05$ compared with the POPE group.

POPEP was further separated using three kinds of UF membranes $(10,000,5000$, and $3000 \mathrm{Da}$ MWCO) according to molecular size, and four kinds of fractions, POPEP-I ( $>10,000$ Da), POPEP-II (5000-10,000 Da), POPEP-III (3000-5000 Da) and POPEP-IV (<3000 Da) were obtained. POPEP-III had the highest antioxidant activity among the four fractions (Figure 2, Table 4). The scavenging activity of POPEP-III for DPPH and $\mathrm{H}_{2} \mathrm{O}_{2}$ was the highest among the samples. The reducing power and $\mathrm{Fe}^{2+}$ chelating activity of POPEP-III exhibited the highest antioxidant activity among these samples. However, all the samples had no significant differences in inhibitory effects on lipid peroxidation. POPEP-III has certain similarities with peptides with alcalase-derived hydrolysate from alfalfa leaf protein [28]. Considering that POPEP-III was found to possess the highest antioxidant activity, this 
fraction was analyzed for molecular weight distribution. The chromatographic data suggested that POPEP-III was composed of molecular weights of $4076 \mathrm{Da}$ and $3287 \mathrm{Da}$ two major fractions.

Table 3. Comparison of in vitro antioxidant effects of P. ostreatus protein hydrolysate: Pep, Pepsin-treated; Try, trypsin-treated; Dis, dispase-treated; Pap, papain-treated and Bro, bromelin-treated. The values are presented as the mean \pm SD.

\begin{tabular}{cccccc}
\hline & $\begin{array}{c}\text { DPPH } \\
\text { Scavenging } \\
\text { Activity (\%) }\end{array}$ & $\begin{array}{c}\mathbf{H}_{2} \mathbf{O}_{2} \\
\text { Scavenging } \\
\text { Activity (\%) }\end{array}$ & $\begin{array}{c}\text { Reducing } \\
\text { Power } \\
(\text { A700nm) }\end{array}$ & $\begin{array}{c}\text { Lipid } \\
\text { Peroxidantion } \\
\text { Inhibitionactivity (\%) }\end{array}$ & $\begin{array}{c}\text { Ferrous Ion } \\
\text { Chelating } \\
\text { Activity (\%) }\end{array}$ \\
\hline Pep & $91.32 \pm 0.60^{* * *}$ & $62.52 \pm 14.42^{*}$ & $0.87 \pm 0.008^{* * *}$ & $63.34 \pm 0.34^{* * *}$ & $84.28 \pm 0.92^{* * *}$ \\
Try & $56.27 \pm 2.30^{*}$ & $43.47 \pm 3.09^{* * *}$ & $0.51 \pm 0.02^{*}$ & $47.56 \pm 0.88^{* * *}$ & $91.06 \pm 0.36^{* * *}$ \\
Dis & $76.51 \pm 0.68^{* * *}$ & $26.37 \pm 2.28^{* * *}$ & $0.90 \pm 0.04 *$ & $70.89 \pm 0.78^{* * *}$ & $84.98 \pm 0.19^{* * *}$ \\
Pap & $89.19 \pm 0.66^{* * *}$ & $54.93 \pm 0.42^{* * *}$ & $0.68 \pm 0.02^{*}$ & $32.17 \pm 0.37^{* *}$ & $49.37 \pm 1.44^{* * *}$ \\
Bro & $49.46 \pm 1.39^{*}$ & $50.34 \pm 2.67^{* *}$ & $0.84 \pm 0.02 * * *$ & $49.26 \pm 0.10^{* * *}$ & $68.22 \pm 0.42^{* * *}$ \\
POPE & $52.64 \pm 0.62$ & $10.01 \pm 1.84$ & $0.49 \pm 0.004$ & $36.89 \pm 0.66$ & $18.05 \pm 0.81$ \\
\hline
\end{tabular}

$\left({ }^{* * *}\right) p<0.001,(* *) p<0.01$, and $\left(^{*}\right) p<0.05$ compared with the POPE group.
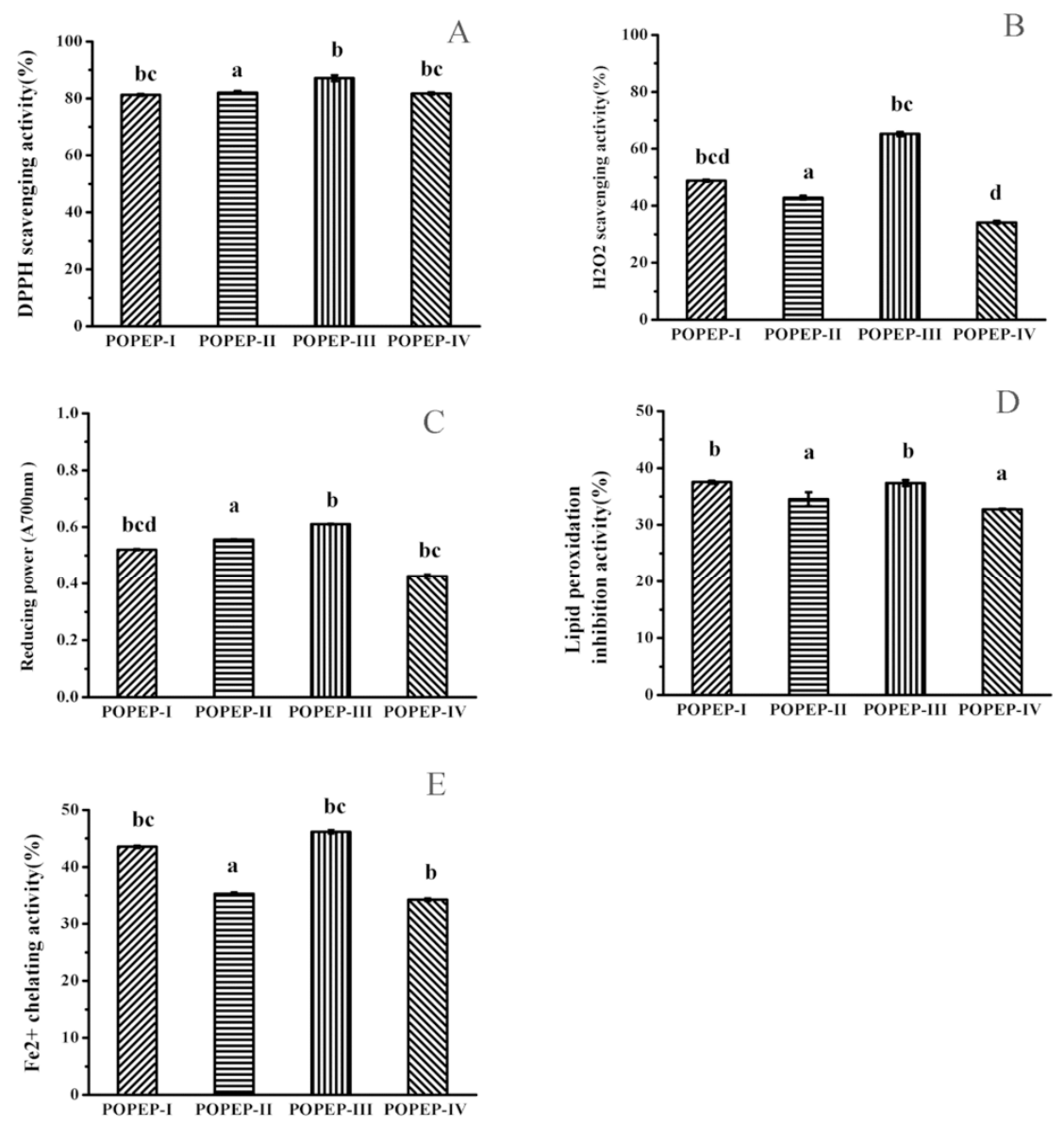

Figure 2. Comparison of in vitro antioxidant effects of different POPEP fractions: (A) DPPH scavenging activity. (B) Hydrogen peroxide scavenging activity (C) Reducing power. (D) Inhibitory effect on lipid peroxidation. (E) $\mathrm{Fe}^{2+}$ chelating activity. The values are presented as the mean values $\pm \mathrm{SD}(\mathrm{n}=3)$, and the same letters above the bars indicate statistically insignificant differences between the groups $(p<0.05)$. 
Table 4. Comparison of in vitro antioxidant effects of different POPEP fractions. The values are presented as the mean $\pm S D(n=3)$. The same letters after the mean indicate statistically insignificant differences between the groups $(p<0.05)$.

\begin{tabular}{cccccc}
\hline & $\begin{array}{c}\text { DPPH } \\
\text { Scavenging } \\
\text { Activity (\%) }\end{array}$ & $\begin{array}{c}\text { H2O2 } \\
\text { Scavenging } \\
\text { Activity (\%) }\end{array}$ & $\begin{array}{c}\text { Reducing Power } \\
\text { (A700nm) }\end{array}$ & $\begin{array}{c}\text { Lipid } \\
\text { Peroxidantion } \\
\text { Inhibitionactivity (\%) }\end{array}$ & $\begin{array}{c}\text { Ferrous Ion } \\
\text { Chelating } \\
\text { Activity (\%) }\end{array}$ \\
\hline POPEP-I & $81.26 \pm 0.40^{\mathrm{b}, \mathrm{c}}$ & $48.79 \pm 0.34^{\mathrm{b}, \mathrm{c}, \mathrm{d}}$ & $0.52 \pm 0.004^{\mathrm{b}, \mathrm{c}, \mathrm{d}}$ & $37.53 \pm 0.24^{\mathrm{b}}$ & $43.56 \pm 0.31^{\mathrm{b}, \mathrm{c}}$ \\
POPEP-II & $82.1 \pm 1.00^{\mathrm{a}}$ & $42.87 \pm 0.60^{\mathrm{a}}$ & $0.56 \pm 0.04^{\mathrm{a}}$ & $34.56 \pm 1.21^{\mathrm{a}}$ & $35.28 \pm 0.35^{\mathrm{b}, \mathrm{c}}$ \\
POPEP-III & $87.15 \pm 0.55^{\mathrm{b}}$ & $65.22 \pm 0.78^{\mathrm{b}, \mathrm{c}}$ & $0.61 \pm 0.004^{\mathrm{b}}$ & $37.38 \pm 0.50^{\mathrm{b}}$ & $46.19 \pm 0.39^{\mathrm{b}, \mathrm{c}}$ \\
POPEP-IV & $81.73 \pm 0.37^{\mathrm{b}, \mathrm{c}}$ & $34.18 \pm 0.50^{\mathrm{d}}$ & $0.43 \pm 0.08^{\mathrm{b}, \mathrm{c}}$ & $32.77 \pm 0.09^{\mathrm{a}}$ & $34.25 \pm 0.35^{\mathrm{b}}$ \\
\hline
\end{tabular}

${ }^{\mathrm{a}-\mathrm{c}}$ values followed by different letters in the table are significantly different $(p<0.05)$, where $\mathrm{c}$ is the lowest value.

Data are presented as mean \pm standard deviation $(n=7)$.

\subsection{Effects of POPEP-III on Liver Weight, HI and Body Weight in Mice}

The changes in liver weight, $\mathrm{HI}$ and body weight, in different experimental groups of mice are shown in Table 5. The liver weight $(p<0.05)$ and HI $(p<0.05)$ increased significantly compared with the normal control after $\mathrm{CCl}_{4}$ treatment. However, it could be mitigated by pretreatment with POPEP-III, similar to the results of pretreatment with bifendate. Additionally, from the data, we note that the HI was partially dose-dependent on POPEP-III. A decrease in body weight was observed in the $\mathrm{CCl}_{4}$-treated groups $(p<0.05)$, but to a certain extent, POPEP-III could alleviate the weight decrease.

Table 5. Effects of POPEP-III on body weight, liver weight, and hepatosomatic index (HI) in $\mathrm{CCl}_{4}$-treated mice.

\begin{tabular}{ccccc}
\hline Treatments & Dose $(\mathbf{m g} / \mathbf{k g})$ & Body Weight $(\mathrm{g})$ & Liver Weight $(\mathrm{g})$ & HI $(\%)$ \\
\hline Normal & - & $34.32 \pm 2.98^{\mathrm{a}}$ & $1.21 \pm 0.14^{\mathrm{b}}$ & $35.1 \pm 2.27^{\mathrm{c}}$ \\
$\mathrm{CCl}_{4}$ only & - & $33.35 \pm 2.15^{\mathrm{a}}$ & $1.43 \pm 0.27^{\mathrm{a}}$ & $42.49 \pm 5.29^{\mathrm{a}}$ \\
$\mathrm{CCl}_{4}+$ Bifendate & 200 & $34.32 \pm 2.35^{\mathrm{a}}$ & $1.24 \pm 0.1^{\mathrm{b}}$ & $36.1 \pm 1.86^{\mathrm{c}}$ \\
$\mathrm{CCl}_{4}+$ POPEP-III & 100 & $34.02 \pm 2.28^{\mathrm{a}}$ & $1.26 \pm 0.13^{\mathrm{a}}$ & $36.36 \pm 4.45^{\mathrm{c}}$ \\
$\mathrm{CCl}_{4}+$ POPEP-III & 200 & $34.02 \pm 2.28^{\mathrm{a}}$ & $1.26 \pm 0.13^{\mathrm{a}}$ & $36.97 \pm 2.54^{\mathrm{c}}$ \\
$\mathrm{CCl}_{4}+$ POPE & 200 & $32.83 \pm 2.41^{\mathrm{a}}$ & $1.26 \pm 0.16^{\mathrm{a}}$ & $38.21 \pm 2.61^{\mathrm{b}}$ \\
\hline
\end{tabular}

a-c values followed by different letters in the column are significantly different $(p<0.05)$, where $\mathrm{c}$ is the lowest value. Data are presented as mean \pm standard deviation $(n=7)$.

\subsection{Effects of POPEP-III on AST, ALT, MDA, GSH-Px, and SOD Activities}

Some acquainted enzymes in serum, such as ALT and AST, were used as biochemical criteria for early acute hepatic damage. As displayed in Figure 3 and Table 6, $\mathrm{CCl}_{4}$ treatment significantly increased the activities of ALT and AST in serum. The activity of ALT is $24.68 \pm 5.64 \mathrm{IU} / \mathrm{L}$ and that of AST is $44.62 \pm 5.25 \mathrm{IU} / \mathrm{L}$ in group I (the normal group). However, the activities of ALT and AST are $365.44 \pm 36.87 \mathrm{IU} / \mathrm{L}$ and $352.52 \pm 13.44 \mathrm{IU} / \mathrm{L}$ respectively, in group II treated with $\mathrm{CCl}_{4}$ only $(p<0.001)$. The pretreatment of POPEP-III reduced the activities of ALT and AST in a dose-dependent manner as caused by $\mathrm{CCl}_{4}\left(p<0.05\right.$ vs $\mathrm{CCl}_{4}$-intoxicated group II). At a dose of $200 \mathrm{mg} / \mathrm{kg}$.bw POPEP-III reduced the ALT and AST activities to $220.23 \pm 22.27 \mathrm{IU} / \mathrm{L}$ and $206.75 \pm 17.26 \mathrm{IU} / \mathrm{L}$, respectively, showing less efficiency than bifendate $(200 \mathrm{mg} / \mathrm{kg} . \mathrm{bw})$, which decreased ALT and AST activities to $114.18 \pm 18.36 \mathrm{IU} / \mathrm{L}$ and $144.57 \pm 21.81 \mathrm{IU} / \mathrm{L}$, respectively.

$\mathrm{CCl}_{4}$ affected the antioxidant parameters of the liver tissue of mice. As shown in Figure $4 \mathrm{~A}$ and Table 7, MDA, the product of membrane lipid peroxidation, its levels increased from $5.28 \pm 1.55 \mathrm{nmol} / \mathrm{mg}$ prot in group I to $15.28 \pm 3.47 \mathrm{nmol} / \mathrm{mg}$ prot $(p<0.001)$ in group II. When treated with POPEP-III ( $100 \mathrm{mg} / \mathrm{kg}, 200 \mathrm{mg} / \mathrm{kg})$, levels of MDA decreased to $12.07 \pm 2.16 \mathrm{nmol} / \mathrm{mg}$ prot in group IV and to $10.04 \pm 2.06 \mathrm{nmol} / \mathrm{mg}$ prot in group V, but all are higher than the level of group III treated with bifendate. More interestingly, the level of group VI treated with POPE was the same as 
that of group II and did not demonstrate positive effects. These results indicate that hydrolysatess are more effective in membrane protection than unhydrolysated POPE but less effective than bifendate.
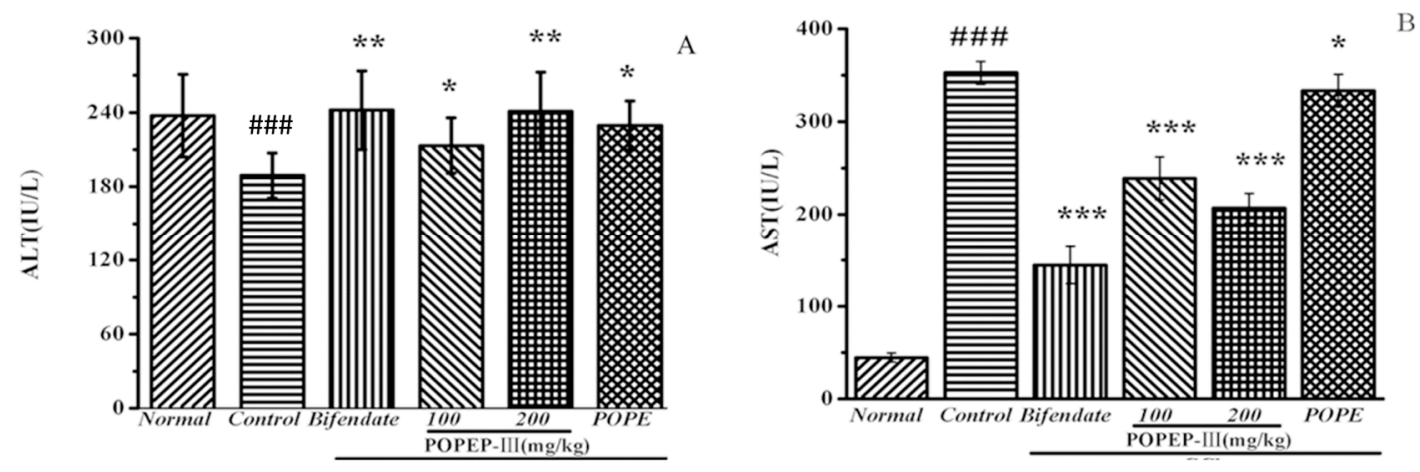

Figure 3. Effects of POPEP-III on the activities of serum ALT (A) and AST (B) in mice. Values are expressed as the mean values $\pm \mathrm{SD}(\mathrm{n}=7)$ : (\#\#\#) $p<0.001$ compared with the normal group; $\left.{ }^{* * *}\right) p<0.001,\left({ }^{* *}\right) p<0.01$, and $\left(^{*}\right) p<0.05$ compared with the $\mathrm{CCl}_{4}$-treated control group.

Table 6. Effects of POPEP-III on the activities of serum ALT and AST in mice.

\begin{tabular}{ccc}
\hline & ALT (IU/L) & AST (IU/L) \\
\hline Normal & $24.68 \pm 5.64$ & $44.62 \pm 5.25$ \\
Control & $365.44 \pm 36.87^{\# \# \#}$ & $352.52 \pm 13.44^{\# \# \#}$ \\
Bifendate & $114.18 \pm 18.36^{* *}$ & $144.57 \pm 21.81^{* * *}$ \\
POPEP-III 100 & $312.53 \pm 24.04^{*}$ & $238.83 \pm 25.17^{* * *}$ \\
POPEP-III 200 & $220.23 \pm 22.27^{* *}$ & $206.75 \pm 17.26^{* * *}$ \\
POPE & $341.93 \pm 27.56^{*}$ & $333.40 \pm 19.04^{*}$ \\
\hline
\end{tabular}

Values are presented as the mean \pm SD: (\#\#\#) $p<0.001$ compared with the normal group; $\left(^{* * *}\right) p<0.001,\left({ }^{* *}\right) p<0.01$, and $\left(^{*}\right) p<0.05$ compared with the $\mathrm{CCl}_{4}$-treated control group.

SOD and GSH-Px protect liver cells from oxidative damage by scavenging superoxide anions. In this work (Figure 4B,C and Table 7), an apparent decrease was observed in the SOD level from $237.65 \pm 36.06 \mathrm{U} / \mathrm{mg}$ prot $(p<0.01$ ) (Group I) to $187.49 \pm 19.81 \mathrm{U} / \mathrm{mg}$ prot (Group II) and in GSH-Px level from $152.11 \pm 12.58 \mathrm{U} / \mathrm{mg}$ prot $(p<0.01$ ) (Group I) to $84.01 \pm 14.54 \mathrm{U} / \mathrm{mg}$ prot (Group II). When treated with POPEP-III at a dosage of $100 \mathrm{mg} / \mathrm{kg}$, the contant of SOD and GSH-Px in Group IV are similar to the level of Group III treated with bifendate, but the contant of SOD and GSH-Px in Group V are lower compared with Group III. Similar to the effect of MDA adjustment, POPE did not demonstrate the positive effect.

As expected, a significant decrease of the MDA and increase of the GSH-Px and SOD enzyme activities occurred with pretreatment of POPEP-III. MDA content, SOD and GSH-Px activity reached $10.04 \pm 2.06 \mathrm{nmol} / \mathrm{mg}$ prot, $233.35 \pm 34.23 \mathrm{U} / \mathrm{mg}$ prot and $115.9 \pm 16.57 \mathrm{U} / \mathrm{mg}$ prot $(p<0.05)$, respectively, and $100 \mathrm{mg} / \mathrm{kg} . \mathrm{bw}$ of POPEP-III had a relatively slighter influence. 

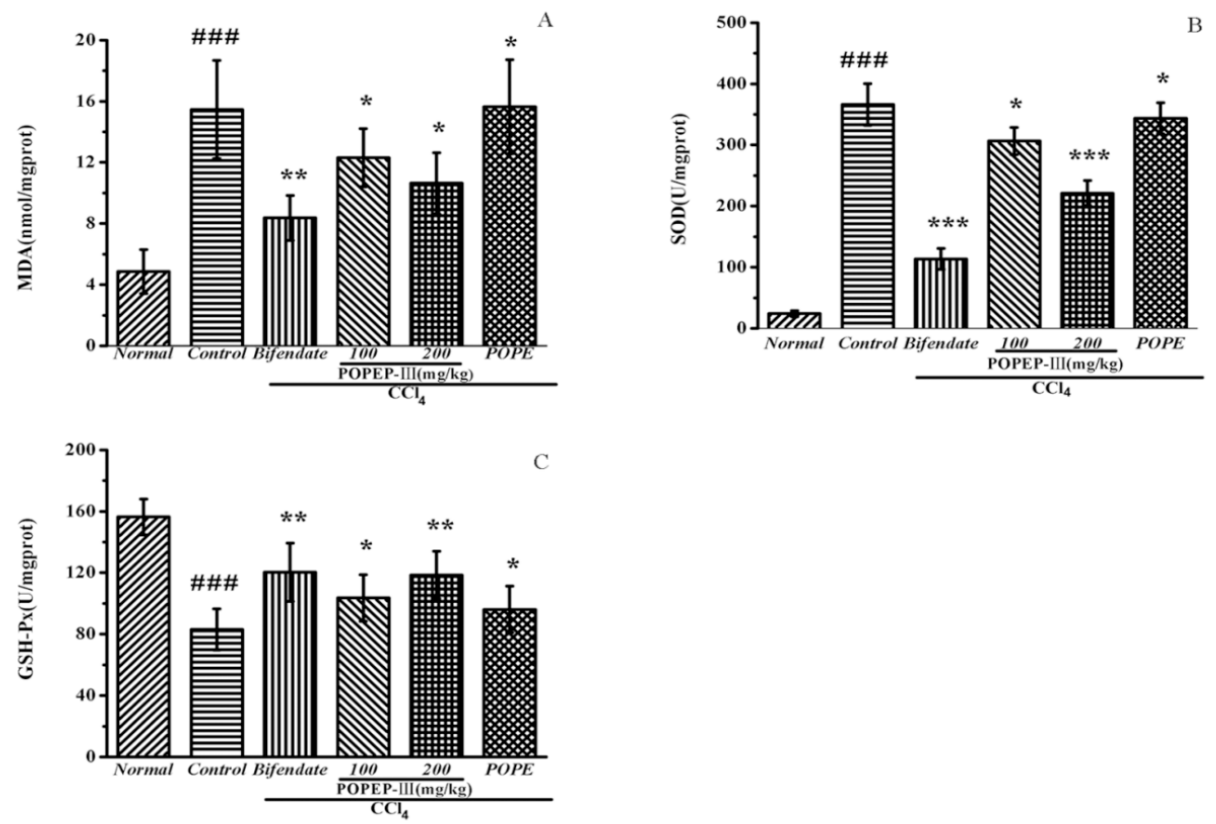

Figure 4. Effects of POPEP-III on hepatic MDA (A), SOD (B) and GSH-Px (C) in mice. Values are expressed as the mean values $\pm \mathrm{SD}(\mathrm{n}=7)$ : $(\# \#) p<0.001$ compared with normal group; $\left({ }^{* * *}\right) p<0.001$, $\left.{ }^{* *}\right) p<0.01$, and $\left.{ }^{*}\right) p<0.05$ compared with the $\mathrm{CCl}_{4}$-treated control group.

Table 7. Effects of POPEP-III on hepatic MDA, SOD and GSH-Px in mice.

\begin{tabular}{cccc}
\hline & $\begin{array}{c}\text { MDA } \\
\text { (nmol/mg prot) }\end{array}$ & $\begin{array}{c}\text { SOD } \\
\text { (U/mg prot) }\end{array}$ & $\begin{array}{c}\text { GSH-Px } \\
\text { (U/mg prot) }\end{array}$ \\
\hline Normal & $5.28 \pm 1.55$ & $237.65 \pm 36.06$ & $152.11 \pm 12.58$ \\
Control & $15.28 \pm 3.47^{\# \# \#}$ & $187.49 \pm 19.81^{\# \# \#}$ & $84.01 \pm 14.54^{\# \#}$ \\
Bifendate & $8.9 \pm 1.58^{* *}$ & $240.11 \pm 34.22^{* * *}$ & $118.12 \pm 20.44^{* *}$ \\
POPEP-III 100 & $12.07 \pm 2.16^{*}$ & $205.65 \pm 24.31^{*}$ & $100.86 \pm 16.37^{*}$ \\
POPEP-III 200 & $10.04 \pm 2.06^{*}$ & $233.35 \pm 34.23^{* * *}$ & $115.9 \pm 16.57^{* *}$ \\
POPEP & $15.01 \pm 3.32^{*}$ & $213.45 \pm 21.45^{*}$ & $86.61 \pm 16.35^{*}$ \\
\hline
\end{tabular}

Values are presented as the mean \pm SD: (\#\#\#) $p<0.001$ compared with normal group; $\left(^{* * *}\right) p<0.001,\left({ }^{* *}\right) p<0.01$, and $\left(^{*}\right) p<0.05$ compared with the $\mathrm{CCl}_{4}$-treated control group.

\subsection{Histopathology Examination}

In this seaction, histopathological observation of the liver was performed to supply further support for the biochemical analysis. Compared with the hepatic cellular architecture of mice tissue from the normal control group (Figure 5A), administration of $\mathrm{CCl}_{4}$ to mice resulted in extensive liver damage characterized by formation of large vacuoles, infiltration of inflammatory cells, severe cellular degeneration, necrosis and nuclear fragmentation (Figure 5B). However, bifendate pretreatment effectively protected the liver against $\mathrm{CCl}_{4}$-induced damage (Figure $5 \mathrm{C}$ ), and pathological observation showed only hepatocyte swelling around portal areas. In addition, POPEP-III pretreatment showed slighter hepatic injury and ameliorated liver damage by diminution of large vacuole formation and attenuation of cellular degeneration (Figure 5D,E). For the undigested protein POPE group (Figure 5F), POPE pretreatment did not markedly improve $\mathrm{CCl}_{4}$-induced acute liver injury. 

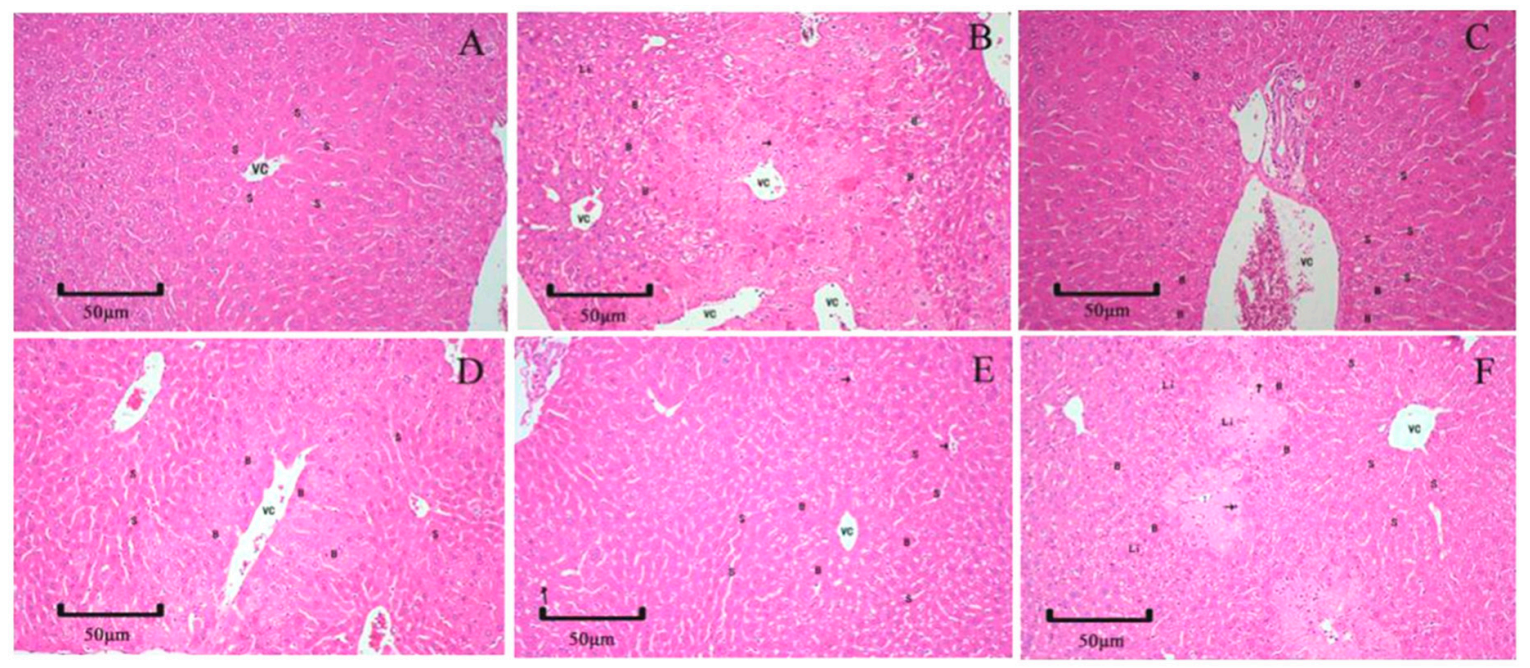

Figure 5. Effects of POPEP-III on $\mathrm{CCl}_{4}$-induced liver histopathological changes in mice $(\times 20 \mathrm{H} \& \mathrm{E}$ staining): (A) Normal group. (B) $\mathrm{CCl}_{4}$ only group $(240 \mu \mathrm{L} / \mathrm{kg} . \mathrm{bw})$. (C) Positive group (200 mg/kg.bw). (D) POPEP-III $+\mathrm{CCl}_{4}(100 \mathrm{mg} / \mathrm{kg} \cdot \mathrm{bw})$. (E) POPEP-III $+\mathrm{CCl}_{4}(200 \mathrm{mg} / \mathrm{kg} \cdot \mathrm{bw})$. (F) POPE $+\mathrm{CCl}_{4}$ (200 mg/kg.bw).

\section{Materials and Methods}

\subsection{Chemicals and Reagents}

The diagnostic kits for activity assays of ALT, AST, MDA, SOD, and GSH-Px were purchased from Nanjing Jiancheng Bioengineering Institute (Nanjing, China). Linoleic acid, DPPH, BSA, and ferrozine were purchased from Sigma-Aldrich (Steinheim, Germany). The UF membrane reactor system for fractionation of hydrolysate was sourced from Sartoyius AG (Goettingen, Germany). For the proteases used in enzymatic hydrolysis, pepsin, trypsin, and dispase were acquired from Sigma-Aldrich (Steinheim, Germany), while papain and bromelin were purchased from Solarbio (Beijing, China). All of the other chemicals used in this study were of analytical grade.

\subsection{Preparation of Crude P. ostreatus Protein}

The procedures used for isolating POPE are those from Souza [29] with some modifications. The fresh fruiting bodies of $P$. ostreatus were purchased from a local farm in Beijing. The preparation of $P$. ostreatus protein extract (POPE) involved a multistep procedure that entailed soaking treatment with deionized water, centrifugation, and extraction with $\mathrm{NaOH}$ solution. Fresh P. ostreatus fruiting bodies were homogenized in deionized water $(1: 1, w / v)$ whith a Waring blender. The homogenate was centrifuged $\left(10,000 \times g, 4{ }^{\circ} \mathrm{C}, 30 \mathrm{~min}\right)$ after overnight extraction at $4{ }^{\circ} \mathrm{C}$. The supernatant was added with $20 \%(w / v) \mathrm{NaOH}$ solution until the concentration of $\mathrm{NaOH}$ reached $0.3 \%(w / v)$ at $25^{\circ} \mathrm{C}$. The dispersion was centrifuged at $10,000 \times \mathrm{g}$ for $20 \mathrm{~min}$ at $4{ }^{\circ} \mathrm{C}$ after a 5 -h stand at room temperature. The obtained precipitate was dialyzed in deionized water for $72 \mathrm{~h}$ to remove free $\mathrm{NaOH}$ and was subsequently lyophilized. This product was POPE.

\subsection{Enzymatic Hydrolysis of POPE}

The lyophilized POPE was dissolved in distilled water to reach a $0.05 \mathrm{~g} / \mathrm{mL}$ concentration. The $\mathrm{pH}$ of the POPE solution was adjusted to the optimal condition for the enzymes used (Table 8). Each enzyme (pepsin, trypsin, dispase, papain, and bromelin) was added proportionally to the POPE solution according to the enzyme/substrate ratio based on the original form of specific enzyme. At the end of the incubation, the solution was heated at $100{ }^{\circ} \mathrm{C}$ for $15 \mathrm{~min}$ to deactivate the enzyme. Hydrolysate was subsequently obtained by centrifugation $\left(10,000 \times \mathrm{g}, 4^{\circ} \mathrm{C}\right.$, and $\left.10 \mathrm{~min}\right)$. hydrolysate was lyophilized for $96 \mathrm{~h}$ at $-70{ }^{\circ} \mathrm{C}$ and $0.04 \mathrm{Mbar}$. All hydrolysates powders were stored at $-20{ }^{\circ} \mathrm{C}$ for further analysis. 
Table 8. Optimal reaction conditions of five proteases.

\begin{tabular}{cccccc}
\hline \multirow{2}{*}{ Protease } & \multirow{2}{*}{ Activity (U/g) } & \multicolumn{4}{c}{ Optimal Conditions } \\
\cline { 3 - 6 } & & Temp. $\left({ }^{\circ} \mathbf{C}\right)$ & $\mathbf{p H}$ & Time (h) & E/S (w/w) \\
\hline Pepsin (Porcine stomach mucosa) & 30,000 & 37 & 2.0 & 3 & $0.5 \%$ \\
Trypsin (Porcine pancreas) & 25,000 & 45 & 8.0 & 5 & $0.5 \%$ \\
Dispase (Bacillus subtilis) & $>60,000$ & 50 & 7.0 & 5 & $0.5 \%$ \\
Papain (Carica papaya) & 800,000 & 45 & 6.2 & 5 & $0.5 \%$ \\
Bromelin (Pineapple) & 600,000 & 45 & 6.0 & 5 & $0.5 \%$ \\
\hline
\end{tabular}

\subsection{Ultrafiltration}

POPEP was sequentially filtrated using three different MWCO ranges UF membranes of 10,000, 5000 , and $3000 \mathrm{Da}$, respectively. The fractions were designed as follows: POPEP-I with MW distribution $>10,000 \mathrm{Da}$, POPEP-II with MW distribution of 5000-10,000 Da, POPEP-III with MW distribution of 3000-5000 Da and POPEP-IV with MW distribution $<3000 \mathrm{Da}$. All four fractions of POPEP were lyophilized. After that, the four fractions were stored at $-20^{\circ} \mathrm{C}$ for further analysis.

\subsection{Degree of Hydrolysis (DH)}

Protein sample solubility was evaluated according to the method of Saeed [30]. Aqueous POPEP solution $(1 \% w / v)$ was prepared at $\mathrm{pH} 7$ (adjusted with either $2 \mathrm{M} \mathrm{HCl}$ or $\mathrm{NaOH})$. Solutions were stirred at room temperature for $30 \mathrm{~min}$ and centrifuged at $1200 \times \mathrm{g}$ for $10 \mathrm{~min}$ at $4{ }^{\circ} \mathrm{C}$. The protein concentration of the supernatant was determined according to the Lowry method [31]. Solubility was expressed as the percent of total protein of the original sample.

\subsection{Analysis of Amino Acid Composition and Molecular Weight Distribution of POPEs}

The lyophilized fractions POPE, POPEP-I, POPEP-II, POPEP-III and POPEP-IV were digested in $\mathrm{HCl}(6.0 \mathrm{M})$ solution at $110^{\circ} \mathrm{C}$ for $24 \mathrm{~h}$ under nitrogen atmosphere. An automated amino acid analyzer (L-8800; Hitachi High Technologies Corp., Tokyo, Japan) equipped with a visible analytical detector was used before post-column derivatization with ninhydrin. Each sample $(1 \mu \mathrm{L})$ was injected into an analytical column (sulfonic cation-exchange resin, $4.6 \mathrm{~mm}$ i.d., $60 \mathrm{~mm}$ length, $3 \mu \mathrm{m}$ particle size; Tokyo, Japan) at $135^{\circ} \mathrm{C}$ with detection at $570 \mathrm{~nm}$. An amino acid standard solution containing 16 amino acids was used as the internal standard.

The POPEP fraction which has the highest antioxidant activity was further analyzed in terms of molecular weight distribution by gel filtration chromatography. The peptides were loaded onto a Sephadex G-25 column $(1.0 \mathrm{~cm} \times 10 \mathrm{~cm}$, GE-Healthcare, Boston, MA, USA) and eluted with deionized water at a flow rate of $0.2 \mathrm{~mL} / \mathrm{min}$. The fractions were collected and monitored at $220 \mathrm{~nm}$. A molecular weight calibration curve was obtained from the following standards: vitamin B12 (1355 Da), L-glutathione (oxidized) (612 Da), L-tyrosine (181 Da), and BSA (6700 Da).

\subsection{Analysis of Antioxidant Activities In Vitro}

\subsubsection{Free Radical Scavenging Activity}

The capacity of all protein hydrolysate fractions tracking free radicals was determined using DPPH [32,33]. The scavenging activity of hydrolysate samples is showed as the percentage disappearance of DPPH relative to a control mixture with deionized water instead of the sample. The mathematical calculations followed Equation (1):

$$
\text { Scavenging of DPPH radical }(\%)=\left(\left(\mathrm{A}_{\text {control }}-\mathrm{A}_{\text {sample }}\right) / \mathrm{A}_{\text {control }}\right) \times 100 \%
$$

where $\mathrm{A}_{\text {control }}$ is the absorbance of the system using deionized water instead of the sample, and $\mathrm{A}_{\text {sample }}$ is the absorbance of the system in the presence of the tested sample. 


\subsubsection{Hydrogen Peroxide Scavenging Activity}

The ability to scavenge hydrogen peroxide $\left(\mathrm{H}_{2} \mathrm{O}_{2}\right)$ was measured following Ganie [34] with some medications. The detection system included $200 \mu \mathrm{L}$ of phosphate buffer $(0.1 \mathrm{M}, \mathrm{pH} 7.4), 40 \mu \mathrm{L}$ of $\mathrm{H}_{2} \mathrm{O}_{2}$ solution $(0.3 \%)$, and $100 \mu \mathrm{L}$ of sample solution $(5 \mathrm{mg} / \mathrm{mL})$, and the absorbance was measured at $230 \mathrm{~nm}$ after $10 \mathrm{~min}$. The scavenging of $\mathrm{H}_{2} \mathrm{O}_{2}$ was calculated as similar to Equation (1).

\subsubsection{Reducing Power}

The reducing power of the peptide samples was measured following our previous work [35]. An amount of $1 \mathrm{~mL}$ of $5 \mathrm{mg} / \mathrm{mL}$ sample solution was mixed with $1 \mathrm{~mL}$ of $0.2 \mathrm{M}$ phosphate buffer saline (pH 6.6) and $1 \mathrm{~mL}$ of $0.1 \% \mathrm{~K}_{3} \mathrm{Fe}(\mathrm{CN})_{6}$ solution and incubated at $50{ }^{\circ} \mathrm{C}$ for $20 \mathrm{~min}$. Then, $1 \mathrm{~mL}$ of $10 \%$ trichloroacetic acid solution was subsequently added. The mixture was centrifuged at $3000 \times g$ for $10 \mathrm{~min}$. Next, $1 \mathrm{~mL}$ of the upper layer was mixed with $1 \mathrm{~mL}$ of distilled water and $0.2 \mathrm{~mL}$ of $0.3 \% \mathrm{FeCl}_{3}$ solution, and the absorbance was measured spectrophotometrically at $700 \mathrm{~nm}$.

\subsubsection{Inhibitory Effect on Lipid Peroxidation}

The inhibitory activity on lipid peroxidation was determined using a slightly modified method of conjugated diene [36]. First, $25 \mu \mathrm{L}$ of sample $(5 \mathrm{mg} / \mathrm{mL})$ was incubated with $500 \mu \mathrm{L}$ of $10 \mathrm{mM}$ linoleic acid emulsion in $0.2 \mathrm{M}$ sodium phosphate buffer ( $\mathrm{pH}$ 6.6) in the dark at $37^{\circ} \mathrm{C}$ for $24 \mathrm{~h}$. Second, $1.5 \mathrm{~mL}$ of $60 \%$ methanol was added. Finally, the mixture absorbance was measured at $234 \mathrm{~nm}$. The inhibitory activity on lipid peroxidation was measured as similar to Equation (1).

\subsubsection{Ferrous Ion Chelating Activity}

The chelating activity on $\mathrm{Fe}^{2+}$ was detected following the procedure described by our earlier study [37] with some modifications. First, $200 \mu \mathrm{L}$ of samples $(5 \mathrm{mg} / \mathrm{mL})$ was mixed with $550 \mu \mathrm{L}$ water and $10 \mu \mathrm{L}$ ferrous chloride $(2 \mathrm{mM})$. The reaction was initiated by adding $40 \mu \mathrm{L}$ of ferrozine $(5 \mathrm{mM})$. The reactant was shaken to evenly mix and held at $25^{\circ} \mathrm{C}$ for $10 \mathrm{~min}$. Finally, the mixture absorbance was measured at $562 \mathrm{~nm}$ against a blank. The $\mathrm{Fe}^{2+}$ chelating activity was expressed as similar to Equation (1).

\subsection{Animal Experiments}

Male Kunming mice (22-25 g) were obtained from Beijing HFK Bioscience Company. The animals were housed for 7 days to acclimatize them to the environment and temperature $\left(20-25^{\circ} \mathrm{C}\right)$ with a $12 \mathrm{~h}$ light/dark cycle. The animals were fed with a standard diet and given water ad libitum.

The in vivo hepatoprotective activity of the POPEP-III was examined against $\mathrm{CCl}_{4}$-induced hepatotoxicity in Kunming mice. Forty-two mice were randomly allocated into six groups (I-VI), with seven mice in each group as follows:

Group normal: normal, normal saline ( $200 \mathrm{mg} / \mathrm{kg}$, i.g.);

Group control: negative control, $\mathrm{CCl}_{4}(12 \mathrm{~mL} / \mathrm{kg}$, i.g.);

Group bifendate: positive control, bifendate $\left(200 \mathrm{mg} / \mathrm{kg}+\mathrm{CCl}_{4}\right.$, i.g.);

Group POPEP-III 100: POPEP-III (100 mg/kg + $\mathrm{CCl}_{4}$, i.g.);

Group POPEP-III 200: POPEP-III (200 mg/kg $+\mathrm{CCl}_{4}$, i.g.);

Group POPE: POPE $\left(200 \mathrm{mg} / \mathrm{kg}+\mathrm{CCl}_{4}\right.$, i.g.).

All groups accepted allocated intragastric administration treatment for 10 successive days. In the normal group and control group, animals received formal saline at a dosage of $(12 \mathrm{~mL} / \mathrm{kg}$, i.g.) once daily, and the mice in bifendate group were treated with bifendate $(200 \mathrm{mg} / \mathrm{kg}$ in distilled water, i.g.) once daily. In the three remaining experimental groups, the mice were pretreated with POPEP-III (100 and $200 \mathrm{mg} / \mathrm{kg}$, i.g.) and POPE (200 mg/kg, i.g.) once daily. On the 11th day, all mice except those in group I received an intraperitoneal gastric perfusion of a $\mathrm{CCl}_{4} / \mathrm{olive}$ oil mixture $(2 \%, 12 \mathrm{~mL} / \mathrm{kg}$, i.g.), and the normal control group received an equal amount of olive oil alone [38]. 
All mice were treated with anesthetic via intraperitoneal injection of pentobarbital sodium (30 mg/kg). Approximately $1 \mathrm{~mL}$ of blood was drawn from the mouse abdominal artery. The blood was allowed to coagulate for $30 \mathrm{~min}$ at room temperature. The serum was isolated by centrifugation at $978 \times g$ for $10 \mathrm{~min}$ at $4{ }^{\circ} \mathrm{C}$ and used in biochemical index detection. The removed livers were washed repeatedly with saline until clean. A small portion of the liver was conserved in $10 \%(v / v)$ formaldehyde for further histopathological analysis, and the remaining liver was homogenized with pre-cooled saline $(1: 9, w / v)$ for biochemical index detection.

\subsection{Biochemical Assays}

The activities of the serum ALT and AST enzymes were assayed according to the guidelines of the diagnostic kits, and the results are showed in IU/L. The liver homogenate in saline solution $(1: 9, w / v)$ was centrifuged at $8000 \times g$ for $10 \mathrm{~min}$ at $4{ }^{\circ} \mathrm{C}$, and the supernatant was collecte. The supernatant was stored at $-20^{\circ} \mathrm{C}$. The activities of SOD, GSH-Px, and MDA content and hepatic protein concentrations in the liver were measured according to the diagnostic kits instructions. The activities of SOD, GSH-Px, and MDA content were normalized with reference to protein, and the results are showed in units per milligram of protein, units per milligram of protein, and nanomoles per milligram of protein. The HI was calculated as the Equation (2):

$$
\mathrm{HI}=(\text { Liver weight } / \text { Body weight }) \times 100 \%
$$

\subsection{Histopathological Study on the Liver}

The fresh liver was removed from each mouse after dissection, and liver tissue was fixed whith $10 \%$ formalin solution. Then the fixed liver tissues were dehydrated in alcohol and embedded in paraffin using the standard microtechnique. Sections $(1.5 \mathrm{~cm} \times 1.5 \mathrm{~cm} \times 5 \mu \mathrm{m})$ stained with hematoxylin and eosin (H\&E) were observed under light microscopy ( $\times 20$ magnification) for histopathological studies [39].

\subsection{Statistical Analysis}

Experimental results are expressed as the mean $\pm \mathrm{SD}$ (standard deviation). The $p$-values $<0.05$ were treated as statistically significant (SPSS, version 20.0).

\section{Conclusions}

In this study, we obtained a peptide named POPEP-III from P. ostreatus by pepsin hydrolysis. POPEP-III exhibit better antioxidant activity in vivo and in vitro. It can significant increase the activity of SOD and GSH-Px, and decrease the content of MAD in serum in mice prior to $\mathrm{CCl}_{4}$. Serum ALT and AST are index of liver, many liver diseases could lead the serum ALT and AST level increase. In our study, POPEP-III can significance decrease the activity of AlT and AST induced by $\mathrm{CCl}_{4}$. The results demonstrate that the POPEP-III could be a liver protect reagent to protect the liver from oxidative damage.

In summary, we hydrolyzed proteins from P. ostreatus fruiting bodies using pepsin and tested the hepatoprotective effects of POPE and POPEP hydrolysate for potential application in health support. The experiments showed that as an antioxidant ingredient, POPEP-III plays a role by halting free radical chain reactions. Additionally, POPEP-III promoted the activities of SOD and GSH-Px, decreased the level of MDA, and protected the liver from the attacks of free radical-mediated ROS.

Author Contributions: Q.L. and H.D.W. conceived and designed the experiments; L.Z., Y.L. (Yuxiao Lu), Q.L. and X.F. performed the experiments and analyzed the data; Y.L. (Yuanhui Li), Y.W., Y.D. and J.H. contributed the reagents, materials, and analysis tools; and L.Z., X.F., Q.L. and H.D.W. wrote the manuscript. All authors have read and agreed to the published version of the manuscript. 
Funding: This research was supported by the National Key R\&D Program (Project No. 2018YFD0400200) from the Ministry of Science and Technology of China. The authors are also grateful for the projects of China Agriculture Research System (Project No. CARS-20-08B) from the Ministry of Agriculture and Rural Affairs of China.

Conflicts of Interest: The authors declare no conflicts of interest.

$\begin{array}{ll}\text { Abbreviations } \\ \text { DPPH } & \text { 1,1-diphenyl-2-picrylhydrazyl } \\ \text { ALT } & \text { alanine aminotransferase } \\ \text { AST } & \text { aspartate aminotransferase } \\ \text { MDA } & \text { malondialdehyde } \\ \text { SOD } & \text { superoxide dismutase } \\ \text { GSH-Px } & \text { glutathione peroxidase } \\ \text { ROS } & \text { reactive oxygen species } \\ \text { HI } & \text { hepatosomatic index } \\ \text { THAA } & \text { total hydrophobic amino acid } \\ \text { BSA } & \text { bovine serum albumin }\end{array}$

\section{References}

1. Gao, B.; Jeong, W.; Tian, Z.G. Liver: An organ with predominant innate immunity. Hepatology 2008, 47, 729-736. [CrossRef] [PubMed]

2. Taub, R.A. Liver regeneration: From myth to mechanism. Nat. Rev. Mol. Cell Biol. 2004, 5, 836-847. [CrossRef] [PubMed]

3. Stoyanovsky, D.A.; Cederbaum, A.I. Thiol oxidation and cytochrome P450-dependent metabolism of $\mathrm{CCl}_{4}$ triggers $\mathrm{Ca}^{2+}$ release from liver microsome. Biochemistry 1996, 35, 15839-15845. [CrossRef] [PubMed]

4. Byass, P. The global burden of liver disease: A challenge for methods and for public health. BMC Med. 2014, 12, 159. [CrossRef] [PubMed]

5. Ronchi, J.A.; Vercesi, A.E.; Castilho, R.F. Reactive oxygen species and permeability transition pore in rat liver and kidney mitoplasts. J. Bioenerg. Biomembr. 2011, 43, 709-715. [CrossRef]

6. Fernandez-Checa, J.C.; Kaplowitz, N. Hepatic mitochondrial glutathione: Transport and role in disease and toxicity. Toxicol. Appl. Pharm. 2005, 204, 263-273. [CrossRef]

7. Paik, Y.H.; Kim, J.; Aoyama, T.; Minicis, S.D.; Bataller, R.; Brenner, D.A. Role of NADPH oxidases in liver fibrosis. Antioxid. Redox Sign. 2014, 20, 2854-2872. [CrossRef]

8. Choi, J.; James Ou, J.H. Mechanisms of Liver Injury. III. Oxidative stress in the pathogenesis of hepatitis C virus. Am. J. Physiol.-Gastrointest. Liver Physiol. 2006, 290, 847-851. [CrossRef]

9. Akanitapichat, P.; Phraibung, K.; Nuchklang, K.; Prompitakkul, S. Antioxidant and hepatoprotective activities of five eggplant varieties. Food Chem. Toxicol. 2010, 48, 3017-3021. [CrossRef]

10. Panda, V.; Ashar, H.; Srinath, S. Antioxidant and hepatoprotective effect of Garcinia indica fruit rind in ethanol induced hepatic damage in rodents. Interdiscip. Toxicol. 2012, 5, 207-213. [CrossRef]

11. Zarezade, V.; Moludi, J.; Mostafazadeh, M.; Mohammadi, M.; Veisi, A. Antioxidant and hepatoprotective effects of Artemisia dracunculus against $\mathrm{CCl}_{4}$-induced hepatotoxicity in rats. Avicenna J. Phytomed. 2018, 8, 51-62. [CrossRef] [PubMed]

12. Bak, M.J.; Jun, M.; Jeong, W.S. Antioxidant and hepatoprotective effects of the red ginseng essential oil in $\mathrm{H}_{2} \mathrm{O}_{2}$-treated HepG2 cells and $\mathrm{CCl}_{4}$-treated mice. Int. J. Mol. Sci. 2012, 13, 2314-2330. [CrossRef] [PubMed]

13. Polyak, S.J.; Morishima, C.; Lohmann, V.; Pal, S.; Lee, D.Y.W.; Liu, Y.Z.; Graf, T.N.; Oberlies, N.H. Identification of hepatoprotective flavonolignans from silymarin. Proc. Natl. Acad. Sci. USA 2010, 107, 5995-5999. [CrossRef] [PubMed]

14. Liu, Q.; Zhu, M.J.; Geng, X.R.; Wang, H.X.; Ng, T.B. Characterization of polysaccharides with antioxidant and hepatoprotective activities from the edible mushroom Oudemansiella radicata. Molecules 2017, 22, 234. [CrossRef]

15. Liu, Q.; Tian, G.T.; Yan, H.; Geng, X.R.; Cao, Q.P.; Wang, H.X.; Ng, T.B. Characterization of polysaccharides with antioxidant and hepatoprotective activities from the wild edible mushroom Russula vinosa Lindblad. J. Agric. Food Chem. 2014, 62, 8858-8866. [CrossRef] 
16. Zhao, H.J.; Zhang, J.J.; Liu, X.C.; Yang, Q.H.; Dong, Y.H.; Jia, L. The antioxidant activities of alkalicextractable polysaccharides from Coprinus comatus on alcohol induced liver injury in mice. Sci. Rep. 2018, 8, 11695. [CrossRef]

17. Sun, J.; He, H.; Xie, B.J. Novel antioxidant peptides from fermented mushroom Ganoderma lucidum. J. Agric. Food Chem. 2004, 52, 6646-6652. [CrossRef]

18. Zhu, B.; Li, Y.Z.; Hu, T.; Zhang, Y. The hepatoprotective effect of polysaccharides from Pleurotus ostreatus on carbon tetrachloride-induced acute liver injury rats. Int. J. Biol. Macromol. 2019, 131, 1-9. [CrossRef]

19. Xia, F.G.; Fan, J.H.; Zhu, M.; Tong, H.B. Antioxidant effects of a water-soluble proteoglycan isolated from the fruiting bodies of Pleurotus ostreatus. J. Taiwan Inst. Chem. E. 2011, 42, 402-407. [CrossRef]

20. Thanaswkaran, J.; Muniyan, S.; Thomas, P.A.; Geraldine, P.L. Pleurotus ostreatus, an oyster mushroom, decreases the oxidative stress induced by carbon tetrachloride in rat kidneys, heart and brain. Chem.-Biol. Interactions 2008, 176, 108-120. [CrossRef]

21. Thanaswkaran, J.; Ramesh, E.; Geraldine, P. Antioxidant activity of the oyster mushroom, Pleurotus ostreatus, on $\mathrm{CCl}_{4}$-induced liver injury in rats. Food Chem. Toxicol. 2006, 44, 1989-1996. [CrossRef]

22. Llauradó, G.; Morris, H.J.; Lebeque, Y.; Venet, G.; Fong, O.; Marcos, J.; Fontaine, R.; Cos, P.; Bermúdez, R.C. Oral administration of an aqueous extract from the oyster mushroom Pleurotus ostreatus enhances the immunonutritional recovery of malnourished mice. Biomed. Pharmacother. 2016, 83, 1456-1463. [CrossRef] [PubMed]

23. Vieira Gomes, D.C.; de Alencar, M.V.O.B.; Dos Reis, A.C.; de Lima, R.M.T.; de Oliveira Santos, J.V.; da Mata, A.M.O.F.; Soares Dias, A.C.; da Costa, J.S.J.; de Medeiros, M.D.G.F.; Paz, M.F.C.J.; et al. Antioxidant, anti-inflammatory and cytotoxic/antitumoral bioactives from the phylum Basidiomycota and their possible mechanisms of action. Biomed. Pharmacother. 2019, 112, 108643. [CrossRef] [PubMed]

24. Gao, W.J.; Sun, Y.H.; Chen, S.W.; Zhang, J.Y.; Kang, J.J.; Wang, Y.Q.; Wang, H.X.; Xia, G.L.; Liu, Q.H.; Kang, Y.M. Mushroom lectin enhanced immunogenicity of HBV DNA vaccine in C57BL/6 and HBsAg-transgenic mice. Vaccine 2013, 31, 2273-2280. [CrossRef] [PubMed]

25. Wang, H.X.; Gao, J.Q.; Ng, T.B. A new lectin with highly potent antihepatoma and antisarcoma activities from the oyster mushroom Pleurotus ostreatus. Biochem. Bioph. Res. Co. 2000, 275, 810-816. [CrossRef] [PubMed]

26. Rajapakse, N.; Mendis, E.; Jung, W.K.; Je, J.Y.; Kim, S.K. Purification of a radical scavenging peptide from fermented mussel sauce and its antioxidant properties. Food Res. Int. 2005, 38, 175-182. [CrossRef]

27. Sun, Q.; Shen, H.X.; Luo, Y.K. Antioxidant activity of hydrolysates and peptide fractions derived from porcine hemoglobin. J. Food Sci. Tech. 2011, 48, 53-60. [CrossRef]

28. Xie, Z.J.; Huang, J.R.; Xu, X.M.; Jin, Z.Y. Antioxidant activity of peptides isolated from alfalfa leaf protein hydrolysate. Food Chem. 2008, 111, 370-376. [CrossRef]

29. Souza, D.; Sbardelotto, A.F.; Ziegler, D.R.; Marczak, L.D.; Tessaro, I.C. Characterization of rice starch and protein obtained by a fast alkaline extraction method. Food Chem. 2016, 191, 36-44. [CrossRef]

30. Saeed, M.; Cheryan, M. Sunflower protein concentrates and isolates low in polyphenols and phytate. J. Food Sci. 1988, 53, 1127-1131. [CrossRef]

31. Lowry, O.H.; Rosebrough, N.J.; Farr, A.L.; Randall, R.J. Protein measurement with the Folin phenol reagent. J. Biol. Chem. 1951, 193, 265-275. [PubMed]

32. Cheng, I.C.; Liao, J.X.; Ciou, J.Y.; Huang, L.T.; Chen, Y.W.; Hou, C.Y. Characterization of Protein Hydrolysates from Eel (Anguilla marmorata) and Their Application in Herbal Eel Extracts. Catalysts 2020, 10, 205. [CrossRef]

33. Wen, T.; Yan, D.D.; Meng, J.; Liu, J.; Xu, H.Y. The enzyme-like property and photocatalytic effect on $\alpha$, $\alpha$-diphenyl- $\beta$-picrylhydrazyl (DPPH) of CuPt nanocomposite. Catalysts 2019, 9, 813. [CrossRef]

34. Pushparaj, F.S.; Urooj, A. Antioxidant activity in two pearl millet (Pennisetum typhoideum) cultivars as influenced by processing. Antioxidants 2014, 3, 55-66. [CrossRef] [PubMed]

35. Li, J.; Huang, S.Y.; Deng, Q.Y.; Li, G.L.; Su, G.C.; Liu, J.W.; Wang, H.M.D. Extraction and characterization of phenolic compounds with antioxidant and antimicrobial activities from pickled radish. Food Chem Toxicol. 2020, 136, 111050-1111055. [CrossRef] [PubMed]

36. Tseng, Y.H.; Yang, J.H.; Mau, J.L. Antioxidant properties of polysaccharides from Ganoderma tsugae. Food Chem. 2008, 107, 732-738. [CrossRef]

37. Chou, H.Y.; Wang, H.M.D.; Kuo, C.H.; Lu, P.H.; Wang, L.; Kang, W.Y.; Sun, C.L. Antioxidant graphene oxide nanoribbon as a novel whiting agent inhibits microphthalmia-associated transcription factor related melanogenesis mechanism. ACS Omega 2020, in press. [CrossRef] 
38. Lu, X.S.; Zhao, Y.; Sun, Y.F.; Yang, S.; Yang, X.X. Characterisation of polysaccharides from green tea of Huangshan Maofeng with antioxidant and hepatoprotective effects. Food Chem. 2013, 141, 3415-3423. [CrossRef]

39. Al-Megrin, W.A.; Alkhuriji, A.F.; Yousef, A.O.S.; Metwally, D.M.; Habotta, O.A.; Kassab, R.B.; Abdel Moneim, A.E.; El-Khadragy, M.F. Antagonistic efficacy of luteolin against lead acetate exposure-associated with hepatotoxicity is mediated via antioxidant, anti-inflammatory, and anti-apoptotic activities. Antioxidants 2020, 9, 10. [CrossRef]

(C) 2020 by the authors. Licensee MDPI, Basel, Switzerland. This article is an open access article distributed under the terms and conditions of the Creative Commons Attribution (CC BY) license (http://creativecommons.org/licenses/by/4.0/). 